\title{
2.3. ETHICAL ASPECTS OF NEGOTIATIONS
}

\begin{abstract}
Summary
Probably because of the egoism and the divergence of interests, people are forced to fight for their corner. It is happening on different plains of the social life, beginning with family, through colleagues' relations, friendship relation and social as well to finish with professional. Therefore it can be said that the negotiations are an indispensable part of our lives.

In organizational disputes, managers negotiate conditions of cooperation with other business entities, employees establish the amount of their wages with the employer, circle the scope of their duties and responsibilities and etc. The interests of individuals or social and professional groups are often represented by the third party (ie. the negotiators) such as organizations as well as trade unions representatives.

Negotiation skills are crucial for establishing business contacts, make new collaborations or maintain already taken business relations.

In practice, the art of negotiation uses a wide range of techniques to help negotiators to achieve the intended purpose. However, some of these techniques raise ethical questions.

The premise of this paper is not willingness of a negative assessment of the strategies adopted by the negotiators, but to show that perspective of the objective of the organization existence is not only to maximize profits for the company owner but social responsibility (ethics) as well. Moral dilemmas and unethical choices which negotiators faced often carry implications acting destructively both in relation to the company'senvironment (eg. contractors, collaborators) for further relationship with the deceived person or subject of negotiations, as well as in relation to the image and conscience of unfair negotiators.
\end{abstract}

Keywords: manager, ethics, negotiation

\section{Characteristics of the term and areas of negotiation ethics}

Negotiations are nowadays a very common practice, concerning all the people and all aspects of social life. We constantly need something that belongs to somebody else, or we compete about something.

Negotiation is " a two-side process of communication, the aim of which is to achieve an agreement, when at least some of the interests of people involved are confrontational" (Fisher et al., 1990). The starting point for negotiations is always conflict, which is "perceived as the cash of different, but interdependent interests" (Mastenbroek, 1998). Therefore, the interdependence of interests (at least one common goal) (Zbiegień-Maciąg, 2003) is the basis for negotiations. They aim to find 
compromise, thanks to which the interests of both sides could be realized, without harm for any of the parties, with simultaneous maximization of profits earned from this cooperation.

Negotiation constitute a different situations from those, where parties are obliged strictly to obide certain external rules. Negotiative practice includes such practices like elevation of the first offer price, which cannot be really considered in terms of morality. Specification and obedience to the rules is completely up to the negotiating parties, not to any external subject, which could impose any sanctions for failure to meet the rules. Should one of the parties break the rules, the second will always see this as something wrong. We should stress however, that some of the negotiative behaviors are very hard to estimate, still we need to consider opinions of all the parties. (Kałążna-Drewińska, 2006)

Focusing on moral issues connected with negotiations, are the basis for extracting from the area of business ethics a category called negotiation ethics. The assumptions of this sub- discipline include both elements of descriptive ethics and normative ethics, both with reference to description of believes and moral behaviors of people as well as stating, what is good and what is wrong in negotiations. (Kamiński, 2007)

Ethical is considered all, which does not contradict moral, legal or social norms. (Kałążna-Drewińska, 2006)

The main areas of interests in case of ethics are: process ethics (I - preparatory stage, II - the essential stage, III - the final stage); ethics of division, ethics of representation, ethics of representation, ethics of intervention. (Kamiński, 2003)

Figure 1: Ethics of negotiation - main interest areas

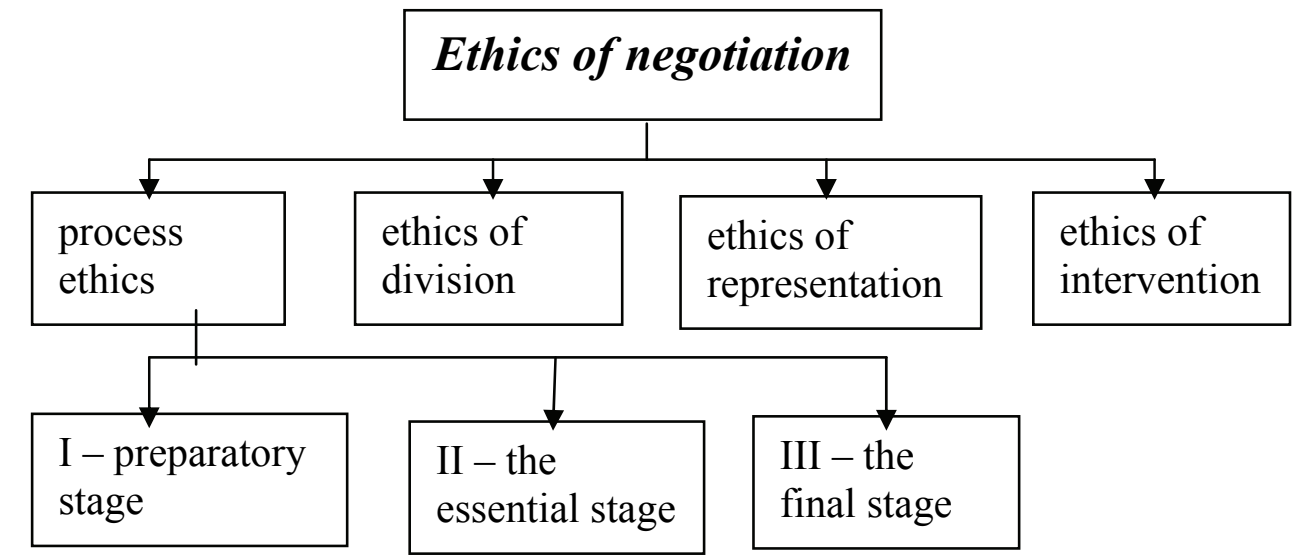

Source: J. Kamiński, negotiation in business. How it is done by organizations, PWE, Warsaw, 2003.

Process ethics is focused on the negotiation flow in various stages: preparatory, essential and final stages.

In the preparatory stage it is common to have contact with moral aspects right while skating the goals. It is possible to endeavor to reach somebody's own goals, or take into account the interest of the other party. Moral aspects in this stage are i. a. the way of getting and using information about the company, negotiators and company 
surroundings. Moreover, the discussed stage is for preparing of the climate for negotiations, that would influence both parties of negotiation. (Kałążna-Drewińska, 2006)

In the Essential stage the most important aspects are the following ethical issues: beginning of the proceedings and preparing of the first offer, a type and way of ma king concessions, order of discussed problems, discussion, type of the questions asked, manipulation of information, using the techniques of influencing others, formulating and signing of a contract. What brings the ethical doubts in the discussed stage of negotiations is the aspect of choosing the correct tactics.

Ethics of the final stage is connected with evaluation of an effect of the negotiation and monitoring of the contract realization.

Ethics of division - stating, whether the result of negotiations is fair, and to which assessment criteria it should undergo.

Ethics of representation - originates from the fact of representation of a party in a negotiation process, e. g. by the agents, lawyers, trainers, psychologists, etc. and resulting problems of moral nature on the line: negotiator- represented person.

Ethics of intervention - is focused on the analysis of the norms and rules of behavior of a mediator, a person that is asked by the negotiating party for help, when they Carnot communicate.

\section{Symptoms of immoral behaviors in negotiations - manipulation and lie}

The original division of negotiation includes hard and soft negotiation. The former are oriented on strengthening cooperation, obtaining satisfactory agreement and avoiding conflicts. They are opposite to the, so called, hard ones, which mainly focus on competition, tension between the parties, using manipulation as an often tool. (Reimus, 2005)

There is also another division of negotiation styles, such as: domination - striving to promote one's own aims at cost of the other party's ones; adaptation - aware giving up one's own aims to support the objectives of the other party, in order to maintain good relationships; avoiding - avoiding any actions, which is based on knowledge, that advantages achievable are not lower than the costs of negotiation; compromise - based on assumption, that negotiation process makes everybody lose something, in order to win something; integrative negotiation - the aim is to work out the agreement creating a new quality useful for both parties. (See further details at http://negocjacje.genialne.info/style_negocjacji.html - odczyt 12.09.2015)

In the books about negotiation, the techniques described as ,ethically doubtful" are the ones which include conscious deception, false statements or twisting facts. (ZbiegienMaciąg, 2003) There are techniques, however, which leave no doubt as above, still including manipulation to some extent (misguiding the receiver). These techniques based mainly on disinformation and emotions, and they are, i.a.:

- good man - bad man - skillful playing roles within one negotiative team. One part of it represents tough position and rejects any compromise; the second one is softer in negotiation, tending to calm down the arguments of the tough part. In 
other words, the negotiators fake the conflict inside the team, convincing this way, that the nicer part"s proposal is the best one can get;

- provocator - a special role aimed at weakening one of the parties, by making them lose control of their emotions. The provocator may use sarcasm, arrogant behavior etc, in order to keep the negotiators focus on controlling their own emotions, preparing retorts or saving their faces instead of concentrating on the problems. This certainly does not help in constructive discussion.

- persuasive manipulation - this leads to omission of some points in negotiation, in a way convenient for the manipulator. The manipulator may behave joyfully, belittling or exaggerating the problems, focusing on irrelevant details or breaking the argumentation with pseudo-rational arguements, like: „that's obvious, why do we need to discuss it at all?". These practices distract the partners, drawing their attention from one's incompetence or weakness. (Zbiegień-Maciąg, 2003)

We can repeat after Mastenbroek, that ,the general rule in negotiation is emotional balance" (Mastenbroek, 1998). A skillful negotiator can control one's emotions, still not by choking them back, or blocking. One is aware of one's reactions, in a way, which makes one's partners understand, that the emotions are controlled, not the other way around. (Fowler 2001)

Ethics of negotiation is focused on various areas, one of the key of them is identification of the symptoms of non-ethical behaviors in a negotiation process. Next, in this process ethics of tactics is extracted (problem of manipulating) and the area called conventionally ethics of false statements (problem of lie). Negotiation tactics aim is to focus our attention to the fact that apart from cooperation and setting goals, apart from tactics cooperation- oriented, there also the ways often using cheating. Therefore, under the above mentioned areas, ethics will be focused on grouping the tactics and statements with similar bases, and next their moral assessment.

Manipulation is ,a group of psychological, propaganda, organizational activities, (...) calculated on effecting particular social and individual behaviors" (Reimus, 2005).

Manipulation is a planned (aimed) and covert activity (which basically decides of its efficiency). Manipulative negotiation forces a person, or a group to accept a false image of specific reality. (Hogan-Speakman, 2009)

During negotiations one can try the following methods of manipulation:

- involving negotiation place - it is based on creating negotiation climate. The negotiation may be organized in dark, isolated places, which is not helpful in obtaining agreement, or in perfect, relaxing conditions, which makes conversation easier and helps to achieve compromise. Uncomfortable chairs, no room for notes, locating negotiation in remote resorts, often phonecalls - these are the tools of a resourceful manipulator to achieve success;

- personal or emotional manipulation (por. L. Cichobłaziński, 2013) - this is the most popular manipulation technique. The manipulator starts a psychological fight on purpose in order to make the negotiators abandon rational arguments and identify themselves with the problems. Classic examples are:

a) „let us love" technique - consists in convincing the opponent of one's friendship, based on common education or career history, which makes the agreement almost obligatory, 
b) cyclical technique - giving high demands in order to change one's attitude radically in the next step. It distracts the opponent and makes him more likely to agree for seemingly irrelevant concession.

c) breaking negotiation - the toughest form of manipulation. This movement is so radical, that, if the negotiation is restarted, the other party is desperate to make an agreement, fearing the situation may repeat itself.

d) personal attack - another form of personal manipulation, used when one of the parties loses its position in substantial argumentation. Than one usually uses the arguement of force. Breaking the rule of emotional and personal neutrality, one starts to accuse and discredit the opponents;

- manipulation with problems - this is used when large problems resolvance is highly unlikely. Then using the baby steps method one tries to resolve the big problem inch by inch;

- manipulation with information - this consists in creating an impression of a well informed person. This evokes respect and has impact on negotiation and its results. This may be only a bluff, which may be easily verified by asking specific questions. Another tactic of this kind is using public surveys. Even though such research needs to be representative, they may be easily used for manipulation by using a group of respondents answering the way we expect them to do. (Reimus, 2005)

We must remember, that the manipulator's priority is to conclude a favorable contract. Persons aware of being treated with dishonest methods will react with counterattack, breaking the negotiation or concession. The first reaction leads to the conflict escalation, which jeopardizes the process of negotiation. Breaking the negotiation is a luxury of those who have a better alternative, and concession is usually the most expected move by the other party. We submit to the opponent's version in order to end the unpleasant situation.

In the literature of a given subject there functions many divisions of the manipulation tactics while negotiating, often very extender. (E. g.

http://katarzynaksiazkiewicz.pl/manipulacja-przewodnik-po-technikachmanipulacyjnych-2/)

Nevertheless, because of the ethical character of the following article, the focus was placed only on the selected examples.

Among the most unpleasant and standing beyond the law tricks and ethically dubious tactics we may distinguish:

1. 1. The use of gifts, parties and other kind of „,bribes” in order to „soften” the position of the other person;

2. Using a group of ,spies” in order to get some special information concerning plans of the other party, mainly concerning established in the point of resistance.

3. Undermining the credibility of a negotiator in front of the board members of his company by using various types of lies;

4. Using various forms of electronic monitoring and heating ( the office of the negotiator, of changing the meetings of the board of directors);

5. Stealing the documents belonging to the opponent, or gaining information from the spys; 
Discreditation or diminishing of the opponents by using public slanders, etc. (http://conradinstitute.org/index.php/rola-prawa-i-etyki-w-prowadzeniu-negocjacji/) Other divisi on of the manipulation tactics will be the one because of:

1. Pressure tactics, which is movements and behaviors, the aim of which is to cause that only one party gives up;

2. Diversion tactics, that are based on the belief, that the negotiator acts according his good belief;

3. Tactics of the psychological war, aiming to cause that the other party of negotiations feels uncomfortably (e.g. too loud, too cold, lack of possibility of consultation, verbal and non-verbal communication causing that the other person feels sorry, and threat), by means of what will be more prone to concession, because its aim is to finish the negotiations as soon as possible. (Fisher et al.. 1990)

Only on the basis of the above mentioned divisions of manipulation tactics it may be concluded that the subject includes many various behaviors, which means from extremely immoral, according to the rule „after corpses for purpose”, or ,purpose sanctifies means", to the less drastic. It is not possible to have them morally assessed according the same criterion (it is, if the observer is a Kantian).

A lie has different form in a process of negotiation. The most common division is the one that distinguishes:

- not full showing the position, which means hiding the point to which the negotiator aims (usually claims, that he would like to achieve more, in order to get what he wants);

- niepełne ujawnianie pozycji, czyli zatajanie punktu do którego zmierza negocjator (zazwyczaj mówi, że chce osiągnąć więcej, aby osiągnąć to czego chce);

- lie, based on cheating being an effect of signalizing intentions of ta king a specific action, although in fact it is not true;

- falsification, refers to the purposeful activities of a negotiator, thanks to which by means of a set of real and unreal arguments lead the other party to false conclusions;

- cheating, is the least sophisticated, among all the forms of lies, based on introducing to negotiations mistaken, false information in order to destroy decisive process of the other party of negotiations.

Ethicists highlight not to confused the above mentioned forms of lies with selective expressing information represented by the parties about the flow of negotiations, because it belongs to the art of negotiating.

\section{Ethical negotiations}

Recently, in the environment of the specialists from the area of negotiations there is more popular point of view that effective negotiator is an ethical negotiator. Nevertheless such a general expression needs to be specified, what is meant by using the word "ethical". The negotiators use in their work various types of tactics and 
techniques that are not always in accordance with the ethical rules. Using i. a. lies, inflating the price, illegal tricks, caused that discussed professional group does not have even good opinion. According to the common opinion there functions a stereotype that negotiator is a person you cannot trust and that is why that person should be constantly carefully observed and listened. Negotiator, in order to be considered as ethical, has to meet several conditions:

- respect your partner,

- reliability - clear intentions for co-workers and the other party, - wellunderstanding among the members of negotiation teams,

- responsibility for words,

- equal right to the utterance - there should be given to the partner the possibility to present his own point of view,

- reciprocity in a process of negotiation - when one party resigns, the second party should lower its claims proportionally (if possible),

- so called ,good manners”- it may be helpful to use diplomatic protocol, as well as ethical code (Rosińska, 2007)

Moreover, negotiator meeting the above mentioned conditions, has the ability to use many techniques that may be used while performing his professional duties. Not all of them are ethically recommended, what should be also taken into account while assessing ethically the work of negotiators.

It should be also taken into account that ethical negotiations should aim to make the agreement probable at the level - the won- the won. Many negotiators make a mistake focusing on the essential aspect of a discussion, removing to the second plan the procedure of resolving the conflict itself. (Fisher et al.. 1990) Correctly organized procedure should be composed of several stages: defining of a problem, looking for an alternative solution and choosing of the best solution. [According to the number of stages the authors are agreed: In terms of the number of stages, the researchers are not unanimous: compare D. Dana, Rozwiazywanie konfliktów, PWE, Warszawa 1993 (4 stages/steps); and Negocjowanie metoda interesów, J.P. Gieorgicy [ed.], Centrum Partnerstwa Społecznego Dialog, Warszawa 1997 (6 stages); lub B. Scott, Negocjowanie, [in:] Praktyka kierowania, D.M. Stewart, PWE, Warszawa 1994 (7 stages)]

The next ethically important aspect of negotiations is taking into consideration some of the universal rules of choosing the fair solution:

- input of work - a party that brings greater work input to the same enterprises, receives greater part of the earned profits;

- equality - parties share profits equally, the input is not meaningful, correspondence to the needs - fair division is the one that takes into account reasonable needs,

- correspondence to the chances - division according to the use that it may be of for the parties; - precedent - the basis of the agreement are solutions from the past (with a given, or different partner) (Rządca- Wujec 1998)

Lewicki and Litterer suggests that a process of ethical negotiations should be encouraged by the following verbal tactics: (Fisher et al. 1990) 
Table 1: The basic tactics supporting process of ethical negotiations

\begin{tabular}{|l|l|}
\hline \multicolumn{1}{|c|}{ Phrases } & \multicolumn{1}{|c|}{ Rules } \\
\hline Please, correct me, if I am wrong. & $\begin{array}{l}\text { Verify the facto in a way that both of the } \\
\text { parties agree with them. }\end{array}$ \\
\hline We appreciate, what you have done for us. & $\begin{array}{l}\text { Separate people from the problem. Help the } \\
\text { other party, even if you have critical attitude } \\
\text { towards his offers. }\end{array}$ \\
\hline Honesty is import ant for us. & Make the negotiations based on the rules. \\
\hline $\begin{array}{l}\text { We would like to resolve this conflict on the } \\
\text { basis of the rules, not selfish interests and } \\
\text { strength. }\end{array}$ & $\begin{array}{l}\text { Protect your own opinion, going back to the } \\
\text { rules, even if the second party tries to bring } \\
\text { them to the private ground. }\end{array}$ \\
\hline $\begin{array}{l}\text { May I ask you some questions in order to } \\
\text { check, whether obtained information is } \\
\text { true? }\end{array}$ & Ask questions, do not make reservations. \\
\hline Which rule is the basis for your action? & $\begin{array}{l}\text { Discover the rules being the basis of the } \\
\text { activities of the other party. }\end{array}$ \\
\hline $\begin{array}{l}\text { Let me check if I understand property what } \\
\text { you have told. }\end{array}$ & Listen actively. \\
\hline $\begin{array}{l}\text { Let me come back to this conversation later. } \\
\text { present considered opinions, consult your } \\
\text { suggestions with the people that you } \\
\text { represent. }\end{array}$ \\
\hline $\begin{array}{l}\text { Let me understand the doubts in perceiving } \\
\text { some of your arguments. }\end{array}$ & $\begin{array}{l}\text { Present explanation before you express your } \\
\text { suggestions. }\end{array}$ \\
\hline $\begin{array}{l}\text { One of the fair solutions could be based } \\
\text { on... }\end{array}$ & $\begin{array}{l}\text { Present your suggestions in the context of } \\
\text { honesty. }\end{array}$ \\
\hline the most comfortable for you. & $\begin{array}{l}\text { Present consequences of an agreement, and a } \\
\text { lack of agreement. }\end{array}$ \\
\hline It would be nice to cooperate with you. & $\begin{array}{l}\text { Let the other party feel that he has the } \\
\text { possibility to influence the final agreement. }\end{array}$ \\
\hline Finish the negotiations with a friendly tone. \\
\hline anement... If we do not
\end{tabular}

Source: R.J. Lewicki i J.A. Litterer, Negotiation, IRWIN, Illinois 1985, p. 126, elaboration on the basis of R. Fisher, W. Ury, B. Patton, Getting to Yes..., s. 117-128 (in Polish edition p. 167-178).

Following the above rules allows to stay in control over the flow of negotiations. By leading to the state of lowering the level of emotions and objectivisation of a conflict and transferring the problems to the substantive ground, the negotiators are able to realize activities aiming to the acceptance of a solution that is optimal for both parties. 


\section{Conclusions}

In practice, many companies tries to resolve a problem of unethical activities, by creating the internal codes of conduct, obligatory and binding for their negotiators. Such code creation is not an easy job, as it requires good knowledge in ethics, as well as specific character of one's entrepreneurial activity and negotiation policy. The essence of ethical codes lies in respectability of their norms, instead of being treated as a collection of necessary limits. The basis for such respectability is responsibility of the parties for the whole negotiation process. The $20^{\text {th }}$ century philosopher, Jean Paul Sartre told, that responsibility is ,an objective awareness of being a perpetrator of an event or item" (Kołakowski-Pomian, 1965). Sense of responsibility makes us think on consequences of our own behavior and our ways to treat people. ${ }^{1}$ We need to remember, that once one uses an unethical technique, an experienced opponent will immediately notice the fact of taking part in a dirty game. That is why manipulation may not lead to the expected results, instead, leading to worsening relationships and making the negotiation harder. (Filek, 2011)

Negotiation is an art of obtaining compromise (otherwise, the notion of dictate would be considered) by means of a conversation leading to mutual concessions, which eventually brings both parties to an agreement. Negotiations may be difficult, longlasting and arduous, but its effect sometimes May be impossible to be underestimated, e. g. avoiding, or abandonment of war in case of international conflicts. Nevertheless, not everyone is allowed to have the honor to negotiate, there are known some examples of the countries' Policy „zero tolerance for terrorism”, in which any concessions towards members of such groups are not accepted (similar in case of e. g. traitors). Therefore, at the beginning of negotiations some of the potential negotiators are excluded, as considered to be unreliable.

In practice, it would be difficult to find negotiations without manipulations (since ancient times the ,ally” of manipulation was the art. of rhetoric), and if we have contact with this phenomenon, negotiations are considered as unprofessional.

How to evaluate moral art of negotiation based on manipulation, various tricks and techniques, if it uses various forms of lies? This question cannot be clearly answered. It would be dependent on the individual, historical and cultural factors. One thing that could be undoubtedly stated is that most of negotiations, regardless the fact whether it is business negotiation, or connected with establishing collective agreement in the times of privatization, or with the trade unions, or national administration, etc. Regardless the fact that the same, sometimes morally ambiguous tactics, it needs to the compromise learning profit for both sides. Arguments, that something is good, because it brings positive effects, undoubtedly caused indignation of many ethics, e. g. giving birth of a healthy baby does not justify rape. According to that, the education in the area of negotiations should be more developed and fight against stereotypes, in order

\footnotetext{
${ }^{1}$ This one is particularly significant problem, especially in terms of another Great Migration Wave. The EU negotiators work under great responsibility for numbers of refugees let in to several countries of European Union.
} 
to have the negotiators to perceive profits and satisfaction from the ethical way of negotiations.

Kamiński in his works on negotiation focuses on efficiency as a criterion, which he understands as one's striving to maximize one's profits, which again, has major influence on the negotiators behaviors. The same profit here is seen as a main reason of unethical solutions in business and negotiation. (Kamiński, 2007) (see also Kamiński, 2003)

Unethical practices, as weel as the ones who use them, should be condemned by the general public. Only such collective influence can guarantee that, unethically obtained profits, will generate losses inevitably in longer perspective.

Summarizing:

- question: what is the method of maintaining ethical standards in negotiation?;

- $\quad$ answer: the persons oriented on moral integrity should be kept convincing, that one should be honest in negotiation (like in general life); the profit oriented persons need to be convinced, that ethical activity is more profitable.

\section{References}

1. Cichobłaziński L (2015): Rola emocji w pracy mediatora w sporach zbiorowych, „Przegląd Socjologii Jakościowej”, t. 9, nr 2, s. 152-163. Dostępny w Internecie: www.przegladsocjologiijakosciowej.org

2. Dana D (1993)., Rozwiązywanie konfliktów, PWE, Warszawa

3. Fisher R., Ury W., Patton B.( 1990): Dochodząc do Tak. Negocjacje bez poddawania się, PEW, Warszawa

4. Filek J (2011)., Wprowadzenie do etyki biznesu, Uniwersytet Ekonomiczny w Krakowie, Kraków

5. Fowler A.(2001): Jak skutecznie negocjować, tłum. Ilona Morżoł, Petit, Warszawa

6. Hogan K., Speakman J (2009): Ukryta perswazja, Helion, Gliwice

7. Kałążna-Drewińska U.(2006): Negocjacje w biznesie. Kluczowe problemy, Wyd. Akademii Ekonomicznej im. Oskara Langego we Wrocławiu, Wrocław

8. Kamiński J.(2003): Negocjowanie w interesach. Jak negocjują organizacje, PWE, Warszawa

9. Kamiński J.(2007): Negocjowanie. Techniki rozwiązywania konfliktów, Wyd. Polontex, Warszawa

10. Lewicki R.J., Litterer J.A (1985)., Negotiation, IRWIN, Illinois

11. Mastenbroek W.(1998): Negocjowanie, PWN, Warszawa

12. Negocjowanie metodą interesów, J.P. Gieorgicy [red.], Centrum Partnerstwa Społecznego Dialog, Warszawa 1997.

13. Reimus T.(2005): Manipulacje w negocjacjach, [w:] Dni Negocjacji II, Ogrodnik D. [red.], Rebis, Poznań

14. Rosińska A., Wizerunek polskiego negocjatora w dobie integracji z Unią Europejską, s. 82.

http://www.instytut.info/images/stories/ksiazki_polecane/16_przemiany_i_perspek tywy_przedsiebiorstw_2/r07.pdf 
15. Rządca R. A., Wujec P (1998): Negocjacje, PWE, Warszawa

16. Sartre J.P (1965): Wolność i odpowiedzialność, [w:] L. Kołakowski, K. Pomian, Filozofia egzystencjalna, PWN, Warszawa .

17. Scott B. (1994): Negocjowanie, [w:] Praktyka kierowania, Stewart D.M. [red.], PWE, Warszawa

18. Zbiegień-Maciąg L.(2003): Taktyki i techniki negocjacyjne, Wyd. AGH, Kraków

19. http://katarzynaksiazkiewicz.pl/manipulacja-przewodnik-po-technikachmanipulacyjnych-2/

20. http://conradinstitute.org/index.php/rola-prawa-i-etyki-w-prowadzeniu-negocjacji/

21. http://negocjacje.genialne.info/style_negocjacji.html - odczyt 12.09.2015 